Authors' contribution/

Wkład autorów:

A. Zaplanowanie badań/

Study design

B. Zebranie danych/

Data collection

C. Analiza statystyczna/

Statistical analysis

D. Interpretacja danych/

Data interpretation

E. Przygotowanie tekstu/

Manuscript preparation

F. Opracowanie

piśmiennictwa/

Literature search

G. Pozyskanie funduszy/

Funds collection
ISSN 2083-3725

\section{TOURISM IN KAMPINOS NATIONAL PARK IN THE OPINION OF VISITORS}

\author{
TURYSTYKA W KAMPINOSKIM PARKU NARODOWYM \\ W OPINII ODWIEDZAJĄCYCH
}

\author{
Małgorzata Gałązka
}

Józef Piłsudski University of Physical Education in Warsaw

Akademia Wychowania Fizycznego Józefa Piłsudskiego w Warszawie

Gałąza M. (2017), Tourism in Kampinos National Park in the opinion of visitors/Turystyka w Kampinoskim Parku Narodowym w opinii odwiedzających. Economic and Regional Studies, Vol. 10, No. 2, pp. 28-38. https://doi.org/10.2478/ers-2017-0013

\section{ORIGINAL ARTICLE}

JEL code: L83, Z32

Submitted:

August 2016

Accepted:

Tables: 0

Figures: 3

References: 11
October 2016

\section{Summary}

Subject and purpose of work: This article analyses a survey of visitors in Kampinos National Park (henceforth also called Kampinos NP) in order to, among others, explore opinions on the most widely cultivated forms of tourist and recreational activity, as well as to learn about the expectations of visitors with regard to the management of the protected area in connection with the preparation of Park to ensure its accessibility for tourist and recreational purposes.

Materials and methods: The study was carried out by the means of the diagnostic survey method, using a questionnaire as an instrument of research. The study group consisted of people visiting Kampinos NP. Results: For visitors, the Park terrain is an ideal place to practice mainly hiking or walking tours and recreational cycling. The park plays a significant role in primarily weekend tourism and recreation, providing a venue for recreational stays and several-hour walks taken by Warsaw agglomeration residents. Conclusions: The research showed that Kampinos NP is one of the best Polish national parks with regard to adaptations for tourism and recreation, as evidenced by one of the densest networks of hiking trails in the country and a wide offer range in terms of natural history and education. In the light of the conducted surveys it can be concluded that the areas of Kampinos NP are well suited for a variety of active tourism and recreation, and the main expectations of visitors focus on appropriate care for the natural environment and small business development.

Keywords: Kampinos National Park, tourism, availability for tourists, recreation

\section{Streszczenie}

ORYGINALNY ARTYKU€ NAUKOWY

Klasyfikacja JEL: L83, Z32

Zgłoszony:

Sierpień 2016

Zaakceptowany:

Październik 2016

Tabele: 0

Rysunki: 3

Literatura: 11
Przedmiot i cel pracy: W artykule dokonano analizy badań przeprowadzonych wśród odwiedzających Kampinoski Park Narodowy m.in. w celu poznania opinii na temat najczęściej uprawianych form aktywności turystyczno-rekreacyjnej, a także poznania oczekiwań odwiedzających względem zarządzających obszarem chronionym w kwestii przygotowania Parku do udostępniania turystyczno-rekreacyjnego. Materiały i metody: Badania zrealizowano za pomocą metody sondażu diagnostycznego z wykorzystaniem ankiety jako narzędzia badań. Grupę badaną stanowiły osoby odwiedzające Kampinoski Park Narodowy. Wyniki: Dla odwiedzających tereny Parku stanowią idealne miejsce do uprawiania głównie turystyki pieszej oraz rekreacyjnej jazdy na rowerze. Park odgrywa znaczącą rolę przede wszystkim w turystyce i rekreacji o charakterze weekendowym, stanowiąc miejsce koncentracji kilkugodzinnych spacerów czy pobytów mieszkańców aglomeracji warszawskiej.

Wnioski: Badania pokazały, że Kampinoski PN jest jednym z lepiej przystosowanych polskich parków narodowych do uprawiania turystyki i rekreacji, o czym świadczy m.in. jedna z gęstszych sieci szlaków turystycznych w kraju i bogata oferta dydaktyczno-przyrodnicza. W świetle przeprowadzonych badań można uznać, że tereny Kampinoskiego PN są dobrze przystosowane do uprawiania różnych form aktywności turystyczno-rekreacyjnej, a główne oczekiwania odwiedzających koncentrują się na odpowiednim dbaniu o środowisko przyrodnicze oraz rozwoju drobnego biznesu prowadzonego przez społeczność lokalną.

Słowa kluczowe: Kampinoski Park Narodowy, turystyka, udostępnienie turystyczne, rekreacja

\footnotetext{
Address for correspondence/ Adres korespondencyjny: dr Małgorzata Gałązka, Akademia Wychowania Fizycznego Józefa Piłsudskiego w Warszawie, Wydział Turystyki i Rekreacji, Marymoncka 34, 00-968 Warszawa, Polska; tel. +48 22 834-04-31 wew. 369; e-mail: galazkama@wp.pl

Journal indexed in/ Czasopismo indeksowane w: AgEcon Search, AGRO, BazEkon, Index Copernicus Journal Master List, ICV 2015: 81,26; Polish Ministry of Science and Higher Education 2016: 9 points / AgEcon Search, AGRO, BazEkon, Index Copernicus Journal Master List ICV 2015: 81,26; Ministerstwie Nauki i Szkolnictwa Wyższego 2016: 9 punktów. Copyright: (C) 2017 Pope John Paul II State School of Higher Education in Biała Podlaska, Małgorzata Gałązka. All articles are distributed under the terms of the Creative Commons Attribution-NonCommercial-ShareAlike 4.0 International (CC BY-NC-SA 4.0) License (http://creativecommons.org/licenses/by-nc-sa/4.0/), allowing third parties to copy and redistribute the material in any medium or format and to remix, transform, and build upon the material, provided the original work is properly
} cited and states its license. 


\section{Introduction}

Kampinos National Park (KNP) is a specific object, as evidenced by its very location just outside the border of Warsaw agglomeration. This arrangement makes it the only national park in Europe and one of the few in the world lying in the direct vicinity of a national capital. Within its area the Park protects the historical and cultural heritage of Kampinos Forest and the unique complex of the best preserved inland dunes in Europe. What determines the attractiveness of the natural landscape is fragmentary patches of swamps as well as the old-growth, very similar to the natural one, character of some forest stands - areas of strict protection in, among others, Nart, Krzywa Góra, Sieraków (Osiński 2002, p. 245).

The importance of the environmental and cultural value of the Park is evidenced by, among others, obtaining the status of UNESCO Biosphere Reserve in 2000 and entry into the European network of protected areas Natura 2000 in 2004 (Regulation of the Minister of Environment on special bird protection areas Natura 2000). It is also the only protected area of this rank in Mazowieckie Voivodeship.

The interweaving of rich wildlife, cultural heritage and history determines the uniqueness of the Park, and makes it stand out in the background of other Polish national parks. Kampinos Forest witnessed numerous battles and clashes during the Second World War, and provided shelter and hideouts for insurgent troops and guerrilla forces. Thus, in the Park there are found numerous graves, cemeteries and monuments commemorating the war and insurgents (including cemetery in Palmiry in Granica, Cross of 'Jeżyki', Insurgents' Oak 1863, Insurgents' Pine 1863. etc.).

Traditions of tourism and recreation development in Kampinos Forest date back to the early twentieth century. Already in 1907, the first organized walking tour across the lowlands was held here. The KNP areas are also among of the most attractive areas for active recreation nearby Warsaw. Due to the location of the Park, tourism and recreation in this area has a mass character and is pursued mainly by Warsaw residents who come to the Park during days off work.

The aim of the study was to explore the opinions and preferences of visitors frequenting Kampinos NP in relation to the current and future character of tourism and recreation in this area.

\section{Tourism in Kampinos National Park}

Already in the mid-nineteenth century Kampinos Forest areas served as a place for hiking tours, which were at the same time characterized by their focus on natural history. The first one was the mentioned walking tour across the lowlands on ${ }^{1}$ June 2nd, 1907 r., held on the initiative of the Polish Tourist Association, with about 380 people participating in it (Herz 2003 p. 174-175).

The first hiking trails for tourists in the Forest appeared in the late $20 \mathrm{~s}$ of the twentieth century

\footnotetext{
${ }^{1}$ Previously, hiking or walking tours were practised only in the mountains.
}

\section{Wstęp}

Kampinoski Park Narodowy (KPN) jest obiektem specyficznym, o czym świadczy fakt jego położenia tuż przy granicy aglomeracji warszawskiej. Takie usytuowanie czyni go jedynym parkiem narodowym w Europie i jednym z kilku na świecie leżących bezpośrednio przy stolicy kraju. Na swoim terenie Park chroni dziedzictwo historyczno-kulturowe Puszczy Kampinoskiej oraz unikatowy kompleks najlepiej zachowanych w Europie wydm śródlądowych. 0 atrakcyjności krajobrazu przyrodniczego decydują fragmenty bagien, a także puszczański, bardzo zbliżony do naturalnego, charakter niektórych fragmentów lasu- obszary ochrony ścisłej m.in. Nart, Krzywa Góra, Sieraków (Osiński 2002,s. 245).

0 znaczeniu walorów przyrodniczych oraz kulturowych Parku świadczy m.in. fakt uzyskania w 2000 r. statusu Rezerwatu Biosfery UNESCO oraz w 2004 r. wpisanie do sieci europejskich obszarów chronionych Natura 2000 (Rozporzadzenie Ministra Środowiska w sprawie obszarów specjalnej ochrony ptaków Natura 2000). Jest on również jedynym obszarem chronionym tej rangi w województwie mazowieckim.

Przenikanie bogactwa przyrodniczego, dziedzictwa kulturowego i historii świadczy o specyfice Par$\mathrm{ku}$, a także stanowi element wyróżniający go na tle pozostałych polskich parków narodowych. Puszcza Kampinoska była świadkiem licznych bitew i starć w czasie II wojny światowej, a także schronieniem dla oddziałów powstańczych i partyzanckich. Stąd na terenie Parku znajdują się liczne mogiły, cmentarze czy pomniki powstańcze i wojenne (m.in. cmentarz w Palmirach, w Granicy, Krzyż „Jeżyków”, Dąb Powstańców 1863 r., Sosna Powstańców 1863 r. itp.).

Tradycje rozwoju turystyki i rekreacji na terenie Puszczy Kampinoskiej sięgają początku XX w. Już w 1907 r. odbyła się tu pierwsza zorganizowana wycieczka piesza po nizinach. Tereny KPN są jednocześnie jednym z najatrakcyjniejszych terenów do aktywnego wypoczynku w okolicach Warszawy. Z uwagi na położenie Parku turystyka i rekreacja na tym terenie mają masowy charakter i uprawiane są głównie przez mieszkańców Warszawy, przyjeżdżających do Parku w dni wolne od pracy.

Celem przeprowadzonych badań było poznanie opinii i preferencji odwiedzających Kampinoski PN w odniesieniu do obecnego jak i przyszłego charakteru turystyki i rekreacji na tym obszarze.

\section{Turystyka w Kampinoskim Parku Narodowym}

Już w połowie XIX w. tereny Puszczy Kampinoskiej służyły wędrówkom pieszym, mającym jednocześnie charakter wycieczek przyrodniczych. Pierwszą z nich była wspomniana wycieczka turystyki pieszej na niżu ${ }^{1} 2$ czerwca 1907 r., która odbyła się z inicjatywy Polskiego Towarzystwa Krajoznawczego (PTK), a uczestniczyło w niej około 380 osób (Herz 2003, s. $174-175$ ).

Pierwsze szlaki turystyczne pojawiły się w Puszczy pod koniec lat 20. XX w. kiedy wyznaczono około

\footnotetext{
${ }^{1}$ Wcześniej turystykę pieszą uprawiano wyłącznie w górach.
} 
when about $113 \mathrm{~km}$ of hiking trails were designated. (Herz 2003 p. 176). In 1959 Kampinos NP was created, which contributed to increasing tourist traffic. Simultaneously, a program modification of the hiking trails in the Park was being prepared. It was implemented during the years 1965-1977, as a result of which in the late 70 s of the twentieth century the network of trails reached about $300 \mathrm{~km}$ in length; most of the trails established back then are still available for tourists (Herz 2003 p. 184). In 19972003, began marking bicycle routes, forming a loop around the Park with a length of approximately 145 $\mathrm{km}$. What is more, several connecting routes were created, forming a network of cycling routes with a total length of over $200 \mathrm{~km}$. Currently the network of trails in Kampinos National Park is approximately $550 \mathrm{~km}$ long (Ochrona Przyrody 2015, p. 278). In the Park, it is possible to practice the following on marked trails: walking tours and recreation, cycling, horse riding as well as cross-country skiing.

Kampinos NP is one of the top most visited national parks in the country. According to the data from the Central Statistical Office since 2000, KNP ranks 5th in this respect. In 1989 the Park was visited by 900 thousand tourists (Raport o stanie, zagrożeniu i ochronie środowiska 1990, p. 170). Since 1997 (when KNP was visited by 600 thousand people), the number of tourists rose steadily (Ochrona Przyrody 1998 p.264) just to reach 1 million visitors in 2000; such attendance of visitors has remained to this day (Ochrona Przyrody 2015, p. 278).

Educational activity in Kampinos National Park is conducted by three institutions: Museum and Education Centre in Granica, Education Centre in Izabelin and the Bison Breeding Centre in Smardzewice. The educational opportunities offered by KNP are used by more than 100 thousand people a year (Markowski, Okołów 2009 p. 44-46). Founded in the 1960s the museum was converted into the Museum and Education Centre in 1990. It is located on the edge of one of the oldest parts of Kampinos Forest the strict protection area "Granica". Since its founding, the Museum and Education Centre has become very popular, which influences the attendance of visitors. Every year the Museum and Education Centre is visited by about $40-60$ thousand of people and $70 \%$ of them are visitors of the Kampinos Forest Museum. The wide offer of the Centre includes the following attractions: museum lessons, shows of films and slide presentations about nature, thematic and training classes, workshops and also ecological games. Since 2000 , the number of Museum visitors has remained stable between 26-30 thousand visitors. The Museum enjoyed the greatest popularity in 2009, when it was visited by 50 thousand people, mostly as a part of the 50th anniversary of the foundation of Kampinos NP and various events, celebrations and scientific conference organized at that time.

Another, and at the same time the main facility for conducting educational activities is the Education Centre in Izabelin, created in 1997. The purpose of its activity is to carry out activities for children and teenagers - lessons and field trips, games and
113 km szlaków pieszych (Herz 2003, s. 176). W 1959 r. utworzono Kampinoski PN, co wpłynęło na wzrost ruchu turystycznego. Równocześnie przygotowano program modyfikacji szlaków turystycznych w Parku, który realizowano w latach 1965-1977, w efekcie czego pod koniec lat 70. XX w. sieć szlaków liczyła około $300 \mathrm{~km}$; większość wytyczonych wtedy tras jest nadal dostępna dla turystów (Herz 2003, s. 184). W latach 1997-2003 przystąpiono do znakowania szlaków rowerowych, tworząc pętlę wokół Parku o długości około $145 \mathrm{~km}$, jak również utworzono kilkanaście szlaków łącznikowych, tworząc sieć szlaków rowerowych o łącznej długości przeszło $200 \mathrm{~km}$. Obecnie sieć szlaków w Kampinoskim PN liczy około $550 \mathrm{~km}$ (Ochrona Środowiska 2015, s. 278). Na obszarze Parku możliwe są do uprawiania po wyznaczonych szlakach turystyka i rekreacja piesza, rowerowa, konna a także narciarstwo śladowe.

Kampinoski PN należy do ścisłej czołówki najczęściej odwiedzanych parków narodowych w kraju. Według danych GUS od 2000 r. KPN znajduje się pod tym względem na 5 miejscu. W 1989 r. Park odwiedziło 900 tys. turystów (Raport o stanie, zagrożeniu i ochronie środowiska 1990, s. 170). Od 1997 r. (kiedy KPN odwiedziło 600 tys. osób) liczba turystów zaczęła sukcesywnie wzrastać (Ochrona Środowiska 1998, s.264), aby w 2000 r. osiągnąć poziom $1 \mathrm{mln}$ odwiedzających; taka frekwencja zwiedzających utrzymuje się do dnia dzisiejszego (Ochrona Środowiska 2015, s. 278).

Działalność edukacyjną w Kampinoskim PN prowadzą trzy placówki: Ośrodek Dydaktyczno-Muzealny w Granicy, Centrum Edukacji w Izabelinie oraz Ośrodek Hodowli Żubrów w Smardzewicach. Z oferty edukacyjnej KPN korzysta ponad 100 tys. osób rocznie (Markowski, Okołów 2009, s. 44-46). Powstałe w latach 60. XX w. muzeum przekształcono w $1990 \mathrm{r}$. w Ośrodek Dydaktyczno-Muzealny położony na skraju jednego z najstarszych fragmentów lasu w Puszczy Kampinoskiej-obszaru ochrony ścisłej „Granica”. Od początku swojego istnienia Ośrodek cieszy się dużą popularnością, co wpływa na frekwencję odwiedzających. Co roku z oferty Ośrodka korzysta około 4060 tys. osób, z czego przeszło 70\% stanowią zwiedzający Muzeum Puszczy Kampinoskiej. W bogatej ofercie edukacyjnej Ośrodka znajdują się m.in. lekcje muzealne, pokazy filmów i slajdów o tematyce przyrodniczej, zajęcia tematyczne, terenowe, warsztatowe i szkoleniowe, a także gry ekologiczne. Od 2000 r. liczba odwiedzających Muzeum kształtowała się mniej więcej na stałym poziomie $\mathrm{w}$ przedziale pomiędzy 26-30 tys. zwiedzających. Największą popularnością Muzeum cieszyło się w 2009 r., kiedy zwiedziło je 50 tys. osób, głównie w ramach 50 rocznicy powstania Kampinoskiego PN oraz organizowanymi w tym czasie różnymi imprezami, uroczystościami i konferencją naukową.

Kolejnym, a zarazem głównym obiektem prowadzącym działalność edukacyjną, jest powstałe w 1997 r. Centrum Edukacji w Izabelinie. Celem jego działalności jest prowadzenie zajęć dla dzieci i młodzieży szkolnej - lekcji i wycieczek terenowych, gier i zabaw, zajęć warsztatowych, pokazów filmów i slaj- 
workshops, shows of films and slide presentations about nature (Okołów 2003 p. 166-167). The centre also coordinates the teaching classes in the whole Park and is responsible for the informative and promotional activities (Okołów 2003, p. 166). In 2014 the Centre organized a total of 54 events (Ochrona Przyrody 2015, p. 281).

An important and attractive part of education in national parks are educational trails, which are part of tourism-oriented development and an effective medium for information related to natural history and environment (Partyka 2010 p. 258). Currently, in the Park 9 educational paths are designated (Ochrona Przyrody 2015, p. 281), allowing one to experience the nature of the Park and natural processes occurring in it.

\section{Materials and methods}

A questionnaire survey was conducted on a group of 1,233 people engaged in various forms of tourist and recreational activity in Kampinos NP. In the statistical analysis, to analyse the correlation between qualitative variables we used the chi-square test of independence with the significance level of 0.05 , checking the strength of the correlation with the Cramer's V coefficient (on the ordering scale) and determining the Kendall's $\tau$ (tau) coefficient. In the case of the analysis of correlation between quantitative and qualitative variables we used MannWhitney's and Kruskal-Wallis's nonparametric tests (both at the significance level of 0.05 ).

The study involved 676 women and 557 men. Most respondents were aged 25-44 (37.8\%) and 45-64 (36.7\%). The rest of respondents were young people up to the age of $24(15.8 \%)$, whereas the smallest group of respondents were above the age of $65(9.7 \%)$.

In terms of the education level the majority of them have higher education (69.9\%) of all people surveyed, in comparison to respondents with secondary education level (27.7\%). Respondents with primary and vocational education levels constituted respectively $1.6 \%$ and $0.8 \%$ of all the respondents.

More than half of the study participants (55.7\%) were white-collar workers, $8.2 \%$ were blue-collar workers and $10.6 \%$ of people performed in other occupations. The rest of respondents were students $(10.9 \%)$, pensioners $(8.4 \%)$, unemployed persons $(3.8 \%)$ and housewives $(2.4 \%)$.

The majority of respondents (68\%) were people living in Warsaw, with the predominance of the respondents from the districts located in the vicinity of Kampinos NP - Bemowo (15.48\%), Bielany (12.14\%), Wola (10.71\%) and to a lesser degree residents of Żoliborz (5.12\%). The smallest group among the surveyed persons were people living in the southern and south-eastern districts of Warsaw agglomeration, such as Bródno and Służew (by $0.12 \%)$, Rembertów (0.24\%), Wesoła (1.31\%), Włochy $(1.67 \%)$ and Wilanów $(1.79 \%)$.

Virtually all respondents from outside of Warsaw (32\% of the total people surveyed) were residents of Mazowieckie Voivodeship, constituting $96.68 \%$ of dów o tematyce przyrodniczej (Okołów 2003, s. 166167). Centrum koordynuje również zajęcia dydaktyczne w skali całego Parku i jest odpowiedzialne za działalność informacyjno-promocyjną (Okołów 2003, s. 166). W 2014 r. Centrum zorganizowało w sumie 54 imprezy (Ochrona Środowiska 2015, s. 281).

Ważnym i atrakcyjnym elementem edukacji w parkach narodowych są ścieżki edukacyjne będące elementem zagospodarowania turystycznego i środkiem efektywnego przekazu informacji przyrodniczych (Partyka 2010, s. 258). Obecnie na terenie Parku wyznaczonych jest 9 ścieżek edukacyjnych (Ochrona Środowiska 2015, s. 281), pozwalających zapoznać się bliżej z przyrodą Parku oraz zachodzącymi w niej procesami przyrodniczymi.

\section{Materiały i metody}

Badania ankietowe przeprowadzono na grupie 1233 osób uprawiających na terenie Kampinoskiego PN różne formy aktywności turystyczno-rekreacyjnej. W analizie statystycznej w przypadku analizy zależności między zmiennymi jakościowymi zastosowano test niezależności chi-kwadrat na poziomie istotności 0,05, sprawdzając siłę związku za pomocą współczynnika V Cramera oraz (przy skali porządkowej) wyznaczając współczynnik $\tau$ (tau) Kendalla. W przypadku analizy zależności między zmienną ilościową a zmienną jakościową zastosowano testy nieparametryczne Manna-Whitneya oraz test Kruskala-Wallisa (oba na poziomie istotności 0,05$)$.

W badaniu wzięło udział 676 kobiet oraz 557 mężczyzn. Większość przebadanych stanowiły osoby w wieku 25-44 lata $(37,8 \%)$ oraz 45-64 lata $(36,7 \%)$. Pozostali przebadani to osoby młode do 24 roku życia $(15,8 \%)$, natomiast najmniejszy odsetek stanowili respondenci powyżej 65 lat $(9,7 \%)$.

Pod względem wykształcenia zdecydowanie przeważali respondenci z wykształceniem wyższym, stanowiąc aż 69,9\% wszystkich przebadanych w porównaniu do $27,7 \%$ osób z wykształceniem średnim. Respondenci z wykształceniem podstawowym i zawodowym stanowili odpowiednio: 1,6\% oraz $0,8 \%$ wszystkich przebadanych.

Ponad połowę respondentów $(55,7 \%)$ stanowili pracownicy umysłowi, 8,2\% pracownicy fizyczni, a $10,6 \%$ osoby wykonujace inne zawody. Pozostali respondenci to uczniowie lub studenci $(10,9 \%)$, emeryci lub renciści $(8,4 \%)$, bezrobotni $(3,8 \%)$ oraz gospodynie domowe $(2,4 \%)$.

Większość respondentów (68\%) stanowiły osoby mieszkające w Warszawie, wśród których przeważali respondenci $\mathrm{z}$ dzielnic położonych $\mathrm{w}$ sąsiedztwie Kampinoskiego PN-Bemowa (15,48\%), Bielan $(12,14 \%)$, Woli $(10,71 \%)$ oraz w mniejszym stopniu mieszkańcy Żoliborza (5,12\%). Najmniej liczną grupę wśród przebadanych stanowiły osoby zamieszkujące południowe i południowo-wschodnie dzielnice aglomeracji warszawskiej, jak Bródno i Służew (po $0,12 \%)$, Rembertów $(0,24 \%)$, Wesoła $(1,31 \%)$ oraz Włochy $(1,67 \%)$ i Wilanów $(1,79 \%)$. 
respondents. Other respondents came from Lódź and Lublin Voivodeships (1.02\% both), from Pomorskie and Warmińsko-Mazurskie Voivodeships (at 0.51\%) and also Dolnośląskie Voivodeship (0.26\%).

\section{Tourism in Kampinos National Park in the opinion of visitors}

The most commonly practised forms of tourism and recreation by respondents in Kampinos NP were recreational walks and strolls in the forest (Figure 1). This form of tourism and leisure with a frequency of several times a month was chosen by almost $13 \%$ of respondents. Walks and strolls are the dominant form of activity in the Park. It results from its location in immediate proximity to a large urban agglomeration; the Park at the same time is seen by local residents as an area for weekend walks lasting several hours and not as an area for active tourism. On the other hand, the residents of the surrounding villages and towns treat the Park terrain as a kind of city park, where one can take a walk, pick berries or mushrooms.

At a frequency of several times a year, respondents most frequently practised hiking (over 39\%), leisure walks (over 38\%) and observed the nature of the Park (33\%). The next forms of activity included, among others, cycling (29\%), adventure tourism (27\%) and passive rest in the forest (23\%).

Some forms of tourism enjoy little popularity. These include e.g. Nordic walking, which is never
Praktycznie wszyscy respondenci spoza Warszawy (32\% ogółu przebadanych) byli mieszkańcami województwa mazowieckiego, stanowiąc 96,68\% badanych osób. Pozostali respondenci pochodzili z województw: lubelskiego i łódzkiego (po 1,02\%), pomorskiego i warmińsko-mazurskiego (po 0,51\%), a także z dolnośląskiego $(0,26 \%)$.

\section{Turystyka w Kampinoskim Parku Narodowym w opinii odwiedzających}

Do najczęściej uprawianych przez respondentów na terenie Kampinoskiego PN form turystyki i rekreacji należały spacery rekreacyjne i przechadzki po lesie (Rysunek 1). Tę formę turystyki i wypoczynku $\mathrm{z}$ częstotliwością kilku razy w miesiącu wybrało prawie 13\% respondentów. Spacery i przechadzki są dominującą formą aktywności na terenie Parku. Wynika to z jego położenia w bezpośrednim sąsiedztwie dużej aglomeracji miejskiej; równocześnie Park jest postrzegany przez mieszkańców, jako teren kilkugodzinnych weekendowych spacerów, a nie jako teren do uprawiania turystyki aktywnej. Z drugiej strony, mieszkańcy okolicznych wsi i miasteczek teren Parku traktują, jako swojego rodzaju park miejski, po którym można odbyć przechadzkę, udać się na zbiór jagód czy grzybobranie.

Z częstotliwością kilku razy w roku respondenci najliczniej uprawiali turystykę pieszą (przeszło $39 \%$ ), spacer rekreacyjny (przeszło 38\%), a także obserwowali przyrodę Parku (33\%). Wśród kolejnych form aktywności znalazły się m.in. przejażdżki rowerowe $(29 \%)$, turystyka krajoznawcza $(27 \%)$ oraz bierny wypoczynek w lesie (23\%).

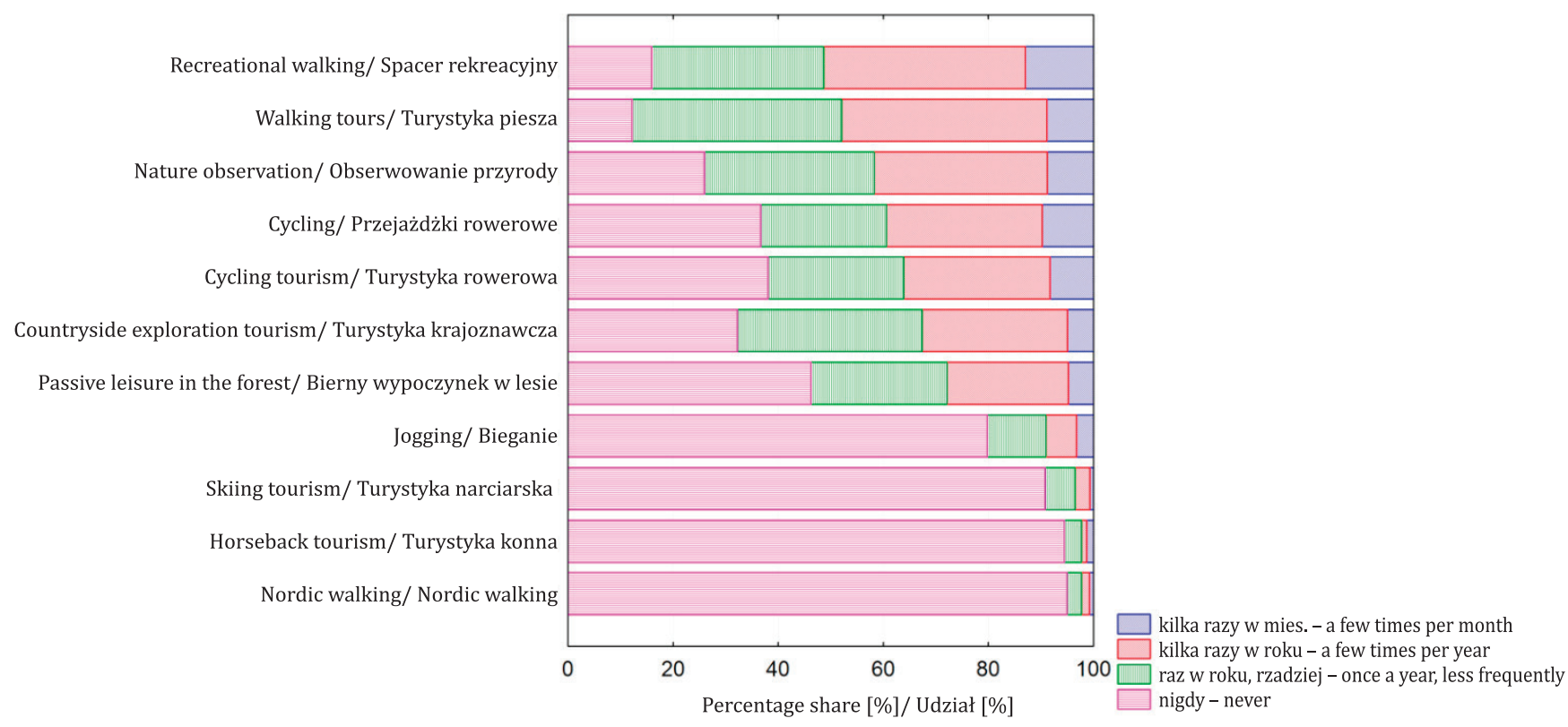

Figure 1. Forms of tourist and recreational activity pursued by visitorsin Kampinos National Park ${ }^{2}$

Rysunek 1. Formy aktywności turystyczno-rekreacyjnej uprawiane przez odwiedzających w Kampinoskim Parku Narodowym ${ }^{2}$ Source: own elaboration based on survey methodology.

Źródło: Opracowanie własne na podstawie przeprowadzonych badań ankietowych.

\footnotetext{
${ }^{2}$ The figure is sorted with respect to the average response to a given statement, as a result of which the statements presented in higher verses are the ones which were on average higher rated by the respondents on the scale./ Rysunek jest sortowany względem średniej odpowiedzi dla danego stwierdzenia, w efekcie czego najwyżej przedstawione są stwierdzenia, które były średnio wyżej oceniane przez respondentów na skali.
} 
practised by $95 \%$ of the survey respondents, horseriding tourism (94\%) and skiing tourism (crosscountry skiing), which more than $90 \%$ of the survey participants are not interested in.

The relationship between the gender of respondents and the choice of the pursued forms of tourist or recreational activity was statistically significant, yet it was characterized by a weak strength of correlation. Correlation with the highest strength was found in the correlation between gender and practicing recreational walks (where $\mathrm{p}$ $<0.001$, Cramer's V coefficient $=0.17$ ). The received data shows that women more often decided to go on walks with a frequency of several times a month $(16 \%)$ and a few times a year $(41 \%)$ when compared with men ( $9 \%$ and $35 \%$ respectively). The relationship between gender and cycling among the respondents also exhibited average strength of correlation $(\mathrm{p}<0.001$, Cramer's $\mathrm{V}=0.14)$. Men constituted a more active group - only $32 \%$ of them have never practised cycling in the Park area in comparison with $43 \%$ of women.

One of the problems that we decided to investigate was the respondents' preferences regarding the amount of tourist traffic in Kampinos NP. The vast majority of the surveyed persons (61\%) were in favour of leaving the amount of tourist traffic unchanged at the level at which it exists at the moment. Quite a large group of the surveyed people believe that the amount of tourist traffic in the Park could be increased (26\%), while $13 \%$ of the respondents preferred reduction of the existing number of visitors.

The relationship between the age of subjects and their opinions on the changes of tourist traffic proved to be statistically significant $(p<0.001)$ It was a relatively strong correlation (Cramer's $V=0.32$ ). At the same time Kendall's coefficient of concordance is also relatively high $(-0.36)$ and indicates a correlation whereby the willingness to develop tourism in Kampinos National Park decreases with age.

It was also decided to examine the expectations of the respondents towards the Park administration (Figure 2). The most important need was the cleanliness of the Park (75\%), maintaining hiking trails in good condition, their preservation as well as legible labelling (69\%). Respondents also pointed to the problem of motor vehicles, such as off-road vehicles or quads moving through the forest and along hiking trails. As many as $67 \%$ of respondents are of the opinion that the authorities of Kampinos NP should take care of this problem because it adversely affects the natural environment, mainly by running over dunes, and tourists themselves are harmed.

More than half of the respondents (52\%) expect the Park administration to solve the problem of unauthorized construction in the Park and in its buffer zone. At the same time $45 \%$ of them believe that the authorities should not grant permission for construction, in most cases of villa or mansion type, emerging with increasing frequency alongside the border of Kampinos NP. Unfortunately, these areas are mostly private property and are sold for development.
Niektóre formy turystyki cieszą się małą popularnością. Należy do nich np. nordic walking, którego nigdy nie uprawiało 95\% przebadanych osób, turystyka konna (94\%) i turystyka narciarska (narciarstwo biegowe, śladowe), którą nie interesowało się ponad $90 \%$ przebadanych.

Zależność między płcią badanych, a wyborem uprawianych form aktywności turystyczno-rekreacyjnej okazała się istotna statystycznie, jednak charakteryzowała się słabą siłą związku. Zależności o najwyższej sile wykazał związek płci z uprawianiem spacerów rekreacyjnych (gdzie p<0,001, współczynnik V Cramera $=0,17)$. Z otrzymanych danych wynika, że kobiety częściej decydowały się na spacery z częstotliwością kilka razy w miesiącu (16\%) i kilka razy w roku (41\%), w porównaniu z mężczyznami (odpowiednio 9\% i 35\%). Średnio silnym związkiem okazała się także zależność płci z uprawianiem turystyki rowerowej przez ankietowanych $(\mathrm{p}<0,001, \mathrm{~V}$ Cramera $=0,14)$. Mężczyźni byli grupą aktywniejszą-tylko $32 \%$ z nich nie uprawiało nigdy turystyki rowerowej na terenie Parku w porównaniu do $43 \%$ kobiet.

Jednym z problemów, jaki postanowiono zbadać były preferencje respondentów, co do wielkości ruchu turystycznego na terenie Kampinoskiego PN. Zdecydowana większość przebadanych (61\%) opowiedziała się za pozostawieniem wielkości ruchu turystycznego bez zmian, na poziomie na jakim istniej on w chwili obecnej. Dość liczna grupa przebadanych osób uważa, że wielkość ruchu turystycznego na terenie Parku można by zwiększyć (26\%), natomiast $13 \%$ respondentów opowiedziało się, za zmniejszeniem istniejącej liczby odwiedzających.

Istotna statystycznie $(p<0,001)$ okazała się zależność między wiekiem badanych, a opinią na temat zmiany ruchu turystycznego. Była to zależność względnie silna (V Cramera $=0,32$ ). Jednocześnie współczynnik Kendalla również jest względnie wysoki $(-0,36)$ i wskazuje, na zależność, że wraz z wiekiem zmniejsza się chęć rozwijania ruchu turystycznego w Kampinoskim PN.

Postanowiono także zbadać oczekiwania respondentów wobec dyrekcji Parku (Rysunek 2). Najistotniejszą potrzebą była czystość terenu Parku (75\%), utrzymywanie szlaków turystycznych w odpowiednim stanie, ich konserwowanie, a także czytelne oznakowanie (69\%). Respondenci zwrócili także uwagę na problem z poruszającymi się po lesie, a także po szlakach turystycznych, pojazdami mechanicznymi typu samochody terenowe czy kłady. Aż 67\% przebadanych jest zdania, że władze Kampinoskiego PN powinny zająć się tym problemem, gdyż cierpi na tym środowisko przyrodnicze m.in. przez rozjeżdżanie wydm, a szkody ponoszą także sami turyści.

Ponad połowa badanych respondentów (52\%), oczekuje od dyrekcji Parku rozwiązania problemu dzikiej zabudowy na terenie samego Parku, jak i w jego otulinie. Jednocześnie $45 \%$ z nich uważa, że władze Parku nie powinny wyrażać zgody na zabudowę, w większości willową, powstającą coraz częściej przy granicy Kampinoskiego PN. Niestety w większości tereny te są własnością prywatną i trafiają do sprzedaży pod zabudowę. 


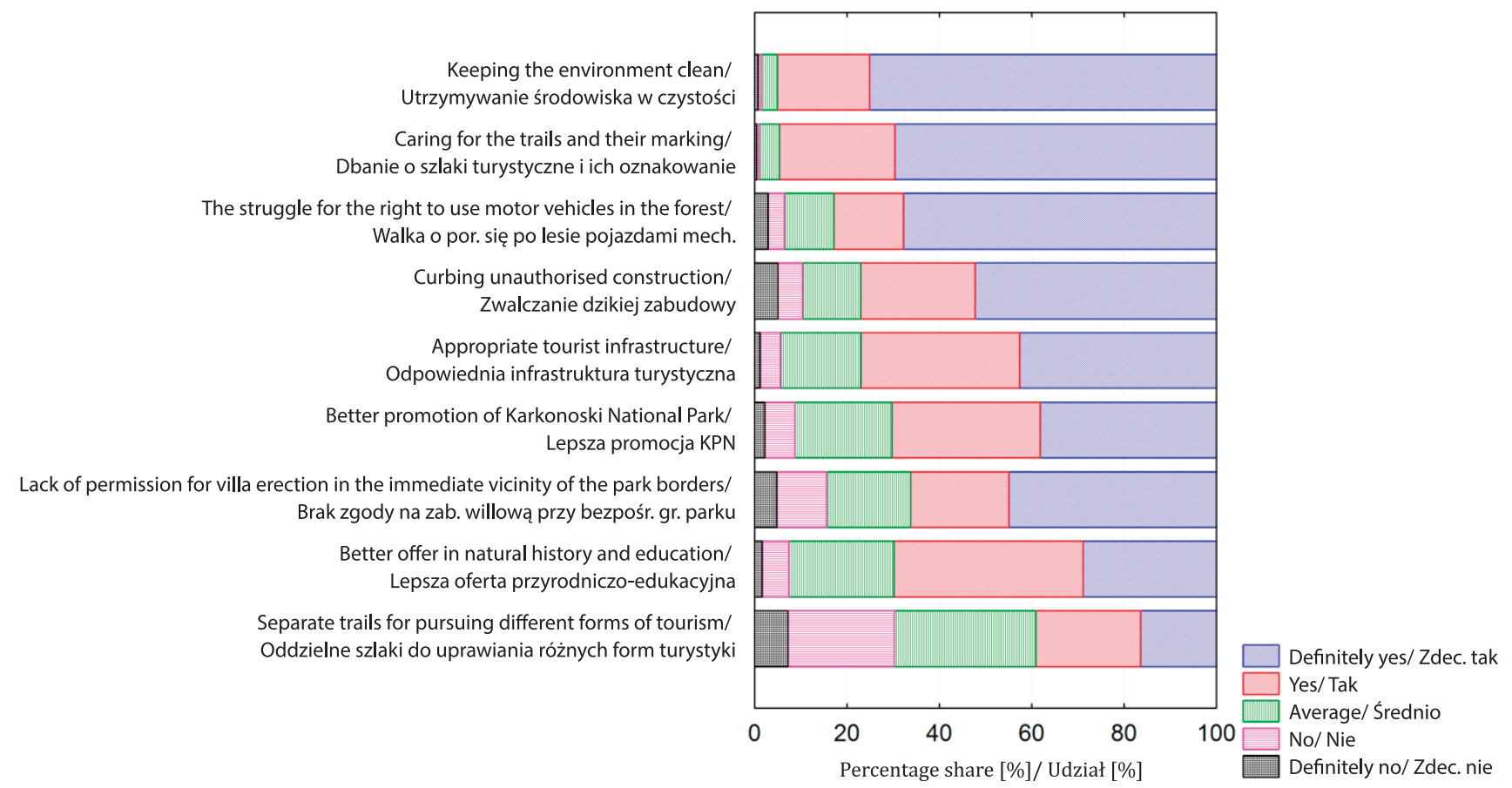

Figure 2. Expectations of respondents in relation to the management of the Kampinos National Park Rysunek 2. Oczekiwania respondentów względem dyrekcji Kampinoskiego Parku Narodowego

Source: own elaboration based on survey methodology.

Źródło: Opracowanie własne na podstawie przeprowadzonych badań ankietowych.

In line with the previous question, it was decided to examine the expectations regarding the development of tourism and recreation in Kampinos National Park which the respondents have in connection with the administration of communes and municipalities in the area where the Park is located. On average, the most frequently chosen expectation, according to the respondents, was appropriate attention to the safety of tourists on the part of commune administration. This response in "yes" options (definitely yes and yes) was chosen by a total of $80 \%$ of all the surveyed persons. The vast majority of respondents (72\%) also expect the local authorities not to issue permits for the construction of housing estates and villas in the immediate vicinity of Kampinos NP. It is not only the protection of the natural environment but also the aesthetics and landscape qualities whose value decreases with the increasing number of buildings in the vicinity of the Park. The third position in the ranking was occupied by the demand to improve public transport facilitating access to the Park - it is mainly about better transport services from western and northern part of Kampinos NP.

The survey also examined what expectations for the development of tourism and recreation in Kampinos NP the respondents had in relation to the population living in the areas within the Park and its buffer zone. Most respondents would like to have an opportunity to purchase fresh agricultural products such as fruit, vegetables, cheese and other ones from the local population (a total of $69 \%$ of responses). Most of the surveyed participants wished for an increase in equipment rental, tourism and recreation
Analogicznie do poprzedniego pytania, postanowiono zbadać, jakie oczekiwania, co do rozwoju turystyki i rekreacji w Kampinoskim PN mają respondenci w stosunku do administracji gmin na terenie, których położony jest Park. Średnio najczęściej wybieranym przez respondentów oczekiwaniem było odpowiednie dbanie przez władze gmin o bezpieczeństwo turystów. Tę odpowiedź w opcjach na „tak” (zdecydowanie tak i tak) wybrało w sumie aż 80\% wszystkich przebadanych. Zdecydowana większość respondentów (72\%) oczekuje także od władz lokalnych nie wydawania zezwoleń na budowę osiedli mieszkaniowych i willi w bezpośrednim sąsiedztwie Kampinoskiego PN. Chodzi tu nie tylko o ochronę środowiska przyrodniczego, lecz również o walory estetyczne i krajobrazowe, których wartość zmniejsza się wraz ze wzrostem liczby zabudowań w sąsiedztwie Parku. Na trzecim miejscu znalazł się postulat polepszenia komunikacji miejskiej, ułatwiającej dojazd-chodzi głównie o lepsze połączenia komunikacyjne, przede wszystkim z zachodnią i północną częścią Kampinoskiego PN.

Zbadano również jakie oczekiwania, co do rozwoju turystyki i rekreacji na terenie Kampinoskiego PN mają respondenci względem ludności zamieszkującej tereny Parku oraz jego otuliny. Respondenci najczęściej chcieliby mieć okazję zakupu od miejscowej ludności świeżych płodów rolnych, takich jak owoce, warzywa, sery i inne (w sumie 69\% odpowiedzi). Większość przebadanych oczekiwałaby także zwiększenia liczby wypożyczalni sprzętu turystyczno-rekreacyjnego (66\%), których w chwili obecnej w okolicach Kampinoskiego PN praktycznie nie ma. Według respondentów powin- 
(66\%), which now is practically absent in the vicinity of Kampinos NP. According to the respondents, it should be possible to rent a bike even if someone does not have their own or is unable to bring it. It would not necessarily be a long-term hire, but even if it is temporary or localized, for example, near parking lots, it would be possible to rent equipment and explore the National Park during weekends. The third most frequently indicated issue by the respondents was increasing the number of food outlets run by the local population (58\%). The survey respondents reported the need to increase the number of agritourism farms and other private accommodation facilities offering overnight stays near the Park. Almost half of all respondents (48\%) believe that the number of accommodation facilities in the vicinity of Kampinos NP should be increased.

The study also explored the opinion of the respondents about what they think about the overall positive effects the development of tourism and recreation may cause in Kampinos NP. The respondents believed that this development may contribute to better fulfilment of the needs in the area of tourism and recreation, both for tourists and the local population (75\%). A large percentage of the surveyed $(61 \%)$ sees the opportunity to raise the level of environmental awareness in the development of tourism and recreation in the Park. Due to its location in the immediate vicinity of Warsaw, the Park plays a significant role in environmental education, especially among school children, who participate in various educational events and workshops organized in the Park. Participation in such kind of activities will certainly contribute to creating an eco-conscious society in the future.

Respondents also felt that the development of tourism and recreation in Kampinos NP could lead to improving the infrastructure of tourism and recreation, both in the Park and in the immediate area, and may have an impact on improving transport accessibility. Among the potential positive effects of the development of tourism and recreation in Kampinos NP, respondents were least likely to pay attention to the typical economic effects, such as the creation of additional jobs for the local population, which results in their income increase, as well as revenue increase for communes administratively associated with the Park.

Similarly, to the previous question, the respondents' opinions about the possible negative effects of tourism development were examined (Figure 3). Among the respondents dropping litter in the Park turned out to be the most frequently chosen negative consequence of tourism and recreation development. Such answer was given by $85 \%$ of respondents. Another problem noticed by the respondents was the disturbance of animals inhabiting Kampinos NP due to excessive tourist traffic ( $71 \%$ positive responses). Treading unplanned paths and deviation from designated hiking trails are common phenomena in protected areas, which also drew the attention of a large percentage of the surveyed (65\%). A similar proportion of respondents na istnieć możliwość wypożyczenia chociażby roweru, jeśli ktoś własnego nie posiada lub nie ma możliwości przewiezienia go. Nie musiałyby to być wypożyczalnie stałe, ale chociażby okresowe, zlokalizowane na przykład przy parkingach, gdzie $\mathrm{w}$ weekend istniałaby możliwość wypożyczenia sprzętu i zwiedzenia terenów Parku. Trzecim najczęściej wskazywanym przez respondentów zagadnieniem było zwiększenie liczby punktów gastronomicznych prowadzonych przez ludność miejscową (58\%). Przebadani zgłaszają także potrzebę zwiększenia liczby gospodarstw agroturystycznych i innych kwater prywatnych, oferujacych noclegi w pobliżu Parku. Prawie połowa wszystkich respondentów (48\%) jest zdania, iż powinno się zwiększyć liczbe miejsc noclegowych w okolicach Kampinoskiego PN.

Badaniu poddano także opinię respondentów na temat, jakie ich zdaniem ogólne pozytywne skutki może wywoływać rozwój turystyki i rekreacji na terenie Kampinoskiego PN. Respondenci uważali, że rozwój ten może wpływać przede wszystkim na lepsze zaspokajanie potrzeb turystycznych i rekreacyjnych, zarówno turystów, jak i ludności miejscowej (75\%). Duży odsetek spośród przebadanych (61\%) dostrzega w rozwoju turystyki i rekreacji na terenie Parku możliwość podniesienia poziomu świadomości ekologicznej społeczeństwa. Ze względu na swoje położenie w bezpośrednim sąsiedztwie Warszawy Park odgrywa znaczącą rolę $w$ edukacji przyrodniczej, przede wszystkim młodzieży szkolnej, która uczestniczy w różnego rodzaju imprezach edukacyjnych czy warsztatach organizowanych w Parku. Udział $\mathrm{w}$ takiego rodzaju zajęciach z całą pewnością wpłynie w przyszłości na powiększenie się świadomego ekologicznie społeczeństwa.

Respondenci uważali również, że rozwój turystyki i rekreacji w Kampinoskim PN może wpłynąć na polepszenia się infrastruktury turystyczno-rekreacyjnej, zarówno na terenie Parku, jak i w jego najbliższej okolicy, jak również może mieć wpływ na poprawienie się dostępności komunikacyjnej. Wśród potencjalnych pozytywnych skutków rozwoju turystyki i rekreacji w Kampinoskim PN najrzadziej respondenci zwracali uwagę na typowo ekonomiczne skutki, jak tworzenie dodatkowych miejsc pracy dla ludności miejscowej, a co za tym idzie wzrost ich dochodów, jak również wzrost dochodów dla gmin związanych administracyjnie Parkiem.

Analogicznie do poprzedniego pytania zbadano opinię respondentów na temat ewentualnych negatywnych skutków, jakie może wywołać rozwój turystyki (Rysunek 3). Zdecydowanie najczęściej wybieranym przez respondentów negatywnym skutkiem rozwoju turystyki i rekreacji okazało się zaśmiecanie terenu Parku. Takiej odpowiedzi udzieliło 85\% przebadanych. Kolejnym, zauważonym przez respondentów problemem było płoszenie, poprzez nadmierny ruch turystyczny, zwierząt zamieszkujących Kampinoski PN (71\% wskazań pozytywnych). Wydeptywanie dzikich ścieżek i zbaczanie z wyznaczonych szlaków turystycznych jest zjawiskiem powszechnym na terenach chronionych, na co również zwrócił uwagę duży odsetek przebadanych (65\%). Podobny odsetek 


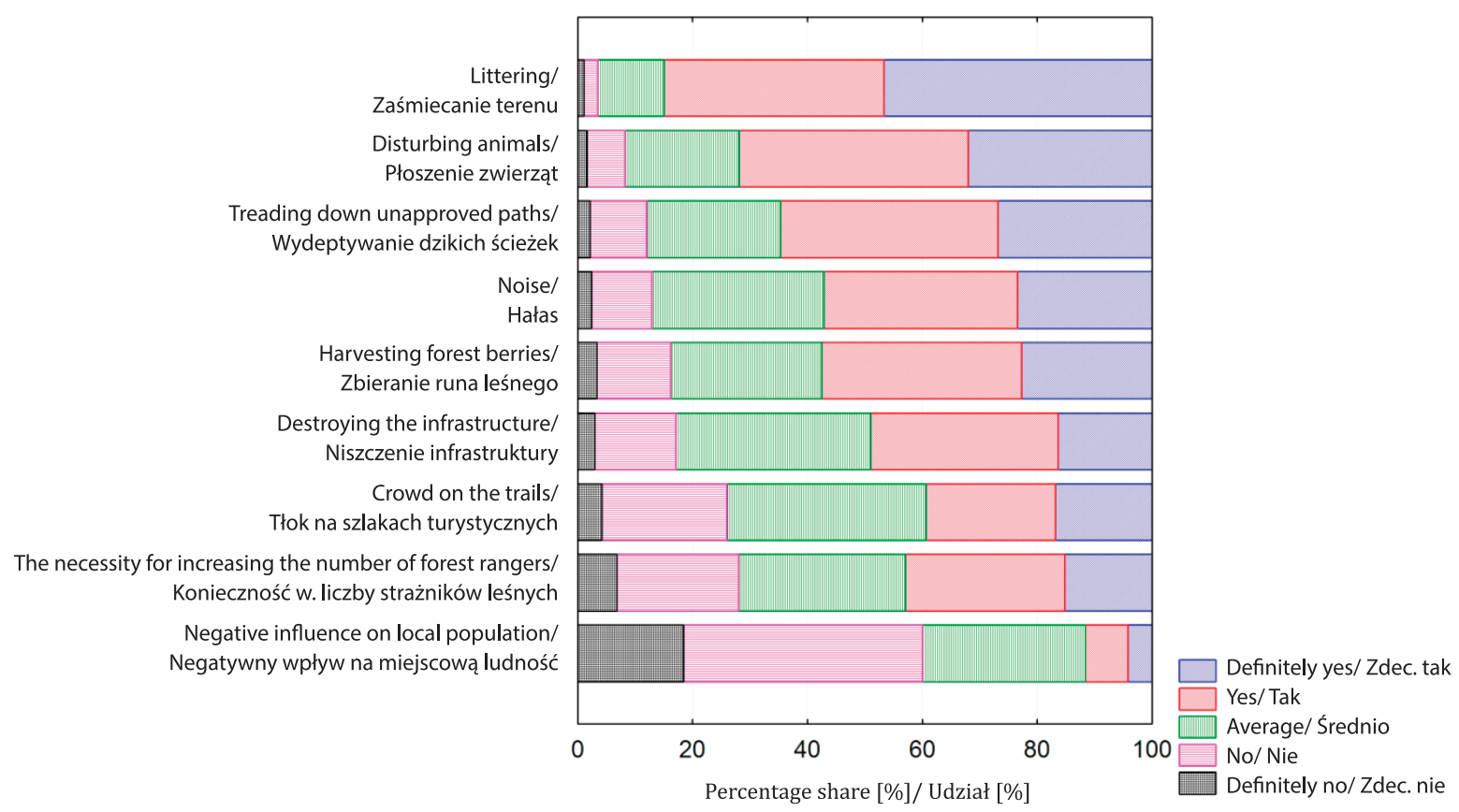

Figure 3. The negative effects of tourism development in Kampinos National Park according to the respondents Rysunek 3. Negatywne skutki rozwoju turystyki w Kampinoskim Parku Narodowym w opinii respondentów

Source: Author's own development based on surveys.

Źródło: Opracowanie własne na podstawie przeprowadzonych badań ankietowych.

also pointed to excessive noise and visitors collecting undergrowth (at 56\%), as some of the negative effects of tourism and recreation development.

It should be noted that according to the respondents the most frequently mentioned potentially negative effects of the development of tourism and recreation in the Kampinos NP, in their opinion, are actually considerable and pose real threat. The research carried out by the author among the residents of Warsaw engaged in tourism in Polish national parks have shown that these are also the most common offenses committed by tourists in the areas of national parks (Gałąka 2008).

During their stays in Kampinos National Park, the residents evaluated their expectations at a very high level of satisfaction, rating it between $90-100 \%$. This evaluation involved general expectations that respondents had in relation to the trip (infrastructure of tourism and recreation, transport accessibility, friendly service, etc.). This was followed by those who have fulfilled expectations of $80-90 \%(21 \%)$, which is a very high level, at $70-80 \%(15 \%)$ and $50-60 \%(10 \%)$ being a satisfactory level.

\section{Conclusions}

Kampinos National Park is one of the largest national parks in the country and is among the better suited for tourism and recreation, as evidenced by, among others, the largest network of hiking trails respondentów wskazał także na nadmierny hałas oraz zbieranie runa leśnego przez odwiedzających (po 56\%), jako jedne z negatywnych skutków rozwoju turystyki i rekreacji.

Należy zwrócić uwagę na to, iż wymieniane najczęściej przez respondentów, potencjalne ich zdaniem, negatywne skutki rozwoju turystyki i rekreacji na terenie Kampinoskiego PN są faktycznie dużym i jak najbardziej realnym zagrożeniem. Przeprowadzone przez autorke badania wśród mieszkańców Warszawy uprawiających turystykę w polskich parkach narodowych pokazały, iż są to jednocześnie najczęściej popełniane przez turystów wykroczenia na obszarach parków narodowych (Gałązka 2008).

Respondenci na bardzo wysokim poziomie oceniali zaspokojenie swoich oczekiwań podczas pobytów w Kampinoskim PN bowiem przeszło 36\% z nich oceniło je na poziomie pomiędzy $90-100 \%$. Ocena ta obejmowała ogół oczekiwań, jakie w związku z wycieczką mieli respondenci infrastruktura turystyczno-rekreacyjna, dostępność komunikacyjna, miła obsługa itp.). Na kolejnych miejscach znalazły się osoby, których oczekiwania spełniły się w 80-90\% (21\%), a więc także na bardzo wysokim poziomie oraz w 70 $80 \%$ (15\%) i 50-60\% (10\%), a więc na poziomie zadowalającym.

\section{Podsumowanie}

Kampinoski Park Narodowy jest jednym z większych parków narodowych w kraju i znajduje się wśród lepiej przystosowanych do uprawiania turystyki i rekreacji, o czym świadczy m.in. największa 
and the number of organized events dedicated to education and natural history.

Visitors of Kampinos NP constitute a diverse group and at the same time, taking into account the suburban nature of the Park, it is a very characteristic group. They are mostly people who are familiar with the area because they live mainly in Warsaw and towns adjacent to the Park area, and stay on its territory usually a few hours during one visit. It is those common and usually lasting up to three hours visits that prove that the Park functions more as a recreational area and not a purely tourist one. Another important feature of Kampinos NP is its well-developed educational function which makes it a destination for many school groups taking part in various natural history workshops. Every year nearly 100 thousand people take advantage of the educational offer of the Park.

The conducted survey shows that the areas of Kampinos NP are ideal for hiking, recreational walking and recreational cycling. The park plays a significant role especially in weekend-long tourism and recreation, providing a venue for several hours of walking or stays by the residents of Warsaw agglomeration. Among the main preferences regarding the future character and shape of tourism and recreation in Kampinos NP, the surveyed persons considered the current scale of tourist traffic, but without increasing the area available for tourism, which could adversely affect the natural environment of the Park.

Respondents visiting the Park evaluated their expectations during stays there at a very high level of satisfaction. Nevertheless, among major negative issues requiring improvement the development of adequate tourist infrastructure (e.g. additional car parks) was given. Also, the relatively poor accessibility of different parts of the Park using public transport was stressed. On the other hand, being aware of the fact that the nature of the Park is its main tourist attraction. residents in their expectations for the Directorate of the Park pointed primarily to the effective protection of the environmental attractions of the area.

Among the main expectations of the local population, the possibility of buying fresh fruit, vegetables and milk from local farms was the most frequently mentioned. At the same time attention was drawn to the need for greater involvement of local communities in the development of tourism services by setting up tourist and recreational equipment rental shops, catering points or the provision of accommodation.

The surveyed tourists expect the municipal authorities to impose restrictions on the issuance of permits for construction of detached houses in the immediate vicinity of the borders of Kampinos NP. Unfortunately, the lack of such restrictions alongside the borders of the Park created entire housing estates. This phenomenon has a negative impact on nature and at the same time, with the increased number of buildings around the Park, it reduces the aesthetic value of the landscape and the area, which visitors sieć szlaków turystycznych oraz liczba organizowanych imprez dydaktyczno-przyrodniczych.

Osoby odwiedzające Kampinoski PN stanowią zróżnicowaną grupę, a jednocześnie biorąc pod uwagę podmiejski charakter Parku jest to grupa dość charakterystyczna. Są to w większości osoby dobrze znające obszar ponieważ mieszkające przede wszystkim w Warszawie lub miejscowościach sąsiadujących z terenem Parku, a jednocześnie przebywające na jego terenie zazwyczaj do kilku godzin. To właśnie te częste i trwające zazwyczaj do trzech godzin odwiedziny stanowią o tym, że Park pełni bardziej funkcję obszaru rekreacyjnego a nie czysto turystycznego. Inną ważną cechą Kampinoskiego PN jest jego dobrze rozwinięta funkcja edukacyjna, co sprawia że jest on celem licznych grup szkolnych biorących udział w różnego rodzaju zajęciach przyrodniczych. Co roku z oferty edukacyjnej Parku korzysta około 100 tys. osób.

Z przeprowadzonych badań ankietowych wynika, że tereny Kampinoskiego PN stanowią idealne miejsce do uprawiania turystyki i rekreacji pieszej oraz rekreacyjnej jazdy na rowerze. Park odgrywa znaczącą rolę przede wszystkim w turystyce i rekreacji o charakterze weekendowym, stanowiąc miejsce koncentracji kilkugodzinnych spacerów czy pobytów mieszkańców aglomeracji warszawskiej. Wśród głównych preferencji dotyczących przyszłego charakteru i kształtu turystyki i rekreacji w Kampinoskim PN ankietowane osoby akceptowały obecną wielkość ruchu turystycznego, jednakże bez powiększania obszarów dostępnych dla turystyki, co mogłoby negatywnie wpłynąć na środowisko przyrodnicze Parku.

Respondenci odwiedzający Park na bardzo wysokim poziomie ocenili zaspokojenie swoich oczekiwań podczas pobytów. Niemniej wśród głównych niekorzystnych zjawisk wymagających poprawy pojawiła się poprawa odpowiedniej infrastruktury turystycznej (m.in. dodatkowe parkingi). Akcentowano również stosunkowo słabe możliwości dojazdu do różnych części Parku komunikacją miejską. Z drugiej strony respondenci w swoich oczekiwaniach względem dyrekcji Parku wskazywali przede wszystkim na skuteczniejszą ochronę walorów przyrodniczych tego obszaru, zdając sobie sprawę z tego, iż przyroda Parku jest jego główną atrakcją turystyczną.

Wśród głównych oczekiwań wobec miejscowej ludności najczęściej wymieniano możliwość zakupu świeżych owoców, warzyw czy mleka z miejscowych gospodarstw. Jednocześnie zwracano uwagę na potrzebę większego zaangażowania się społeczności lokalnej w rozwój usług turystycznych poprzez otwieranie wypożyczalni sprzętu turystyczno-rekreacyjnego, punktów gastronomicznych czy oferowania noclegów.

Przebadani turyści ze strony władz gminnych oczekują ograniczeń w wydawaniu zezwoleń na budowę domów jednorodzinnych w bezpośrednim sąsiedztwie granic Kampinoskiego PN. Niestety wobec braku takich obostrzeń przy granicach Parku powstają całe osiedla mieszkaniowe. Zjawisko to ma negatywny wpływ na przyrodę i jednocześnie wraz ze wzrostem liczby zabudowań wokół Parku zmniejsza się wartość walorów estetycznych i krajobrazowych tych terenów, 
pay attention to. Tourists arriving at Kampinos NP expect better public transport connections from the local authorities, as well as improvement of the roads, which would facilitate travelling to the Park. However, out of the eight municipalities, in recent years only three have taken any action to improve the quality of road access. Visitors of Kampinos NP also claim that the local administration should take care of the construction of parking lots with an adequate infrastructure and amenities accompanying tourism and recreation.

In the light of the study it can be concluded that the area of Kampinos NP is well suited for a variety of active tourism and recreation, and the main expectations of visitors focus on the appropriate care for the natural environment and business development, which not only visitors but also the local community could benefit from. na co odwiedzający zwracają uwagę. Turyści przyjeżdżający do Kampinoskiego PN oczekują także od władz lokalnych lepszych połączeń w komunikacji miejskiej, a także poprawy stanu dróg dojazdowych, co ułatwiłoby dojazdu do Parku. Jednakże spośród ośmiu gmin, jedynie trzy $w$ ostatnich latach podjęły jakiekolwiek działania w zakresie poprawy jakości dróg dojazdowych. Odwiedzający Kampinoski PN uważają również, iż administracja lokalna powinna zająć się budową parkingów z odpowiednią infrastrukturą i bazą towarzyszącą turystyce i rekreacji.

W świetle przeprowadzonych badań można uznać, że tereny Kampinoskiego PN są dobrze przystosowane do uprawiania różnych form aktywności turystyczno-rekreacyjnej, a główne oczekiwania odwiedzających koncentrują się na odpowiednim dbaniu o środowisko przyrodnicze oraz rozwoju działalności, z której korzyści miałaby także społeczność lokalna a nie sami odwiedzający.

\section{References/Literatura:}

1. Gałązka M. (2008), Aktywność turystyczna mieszkańców Warszawy w polskich parkach narodowych, W: W. Siwiński, R. Dawid, E. Mucha-Szajek (red.), Współczesne tendencje w rekreacji i turystyce. Wyższa Szkoła Hotelarstwa i Gastronomii w Poznaniu, Poznań, s. 199-210.

2. GUS (1990), Raport o stanie, zagrożeniu i ochronie środowiska 1990. GUS, Warszawa.

3. GUS (1998), Ochrona Środowiska 1998. GUS, Warszawa.

4. GUS (2015), Ochrona Środowiska 2015. GUS, Warszawa.

5. Herz L. (2003), Turystyka w Kampinoskim Parku Narodowym, W: R. Andrzejewski (red.), Kampinoski Park Narodowy. t. 2, Kampinoski Park Narodowy, Izabelin, s. 173-199.

6. Markowski M., Okołów G. (2009), Działalność Kampinoskiego Parku Narodowego i oferta dla społeczeństwa. Materiały z konferencji popularno-naukowej nt. „50 lat Kampinoskiego Parku Narodowego - funkcje oraz znaczenie w środowisku przyrodniczym i społecznym", Kampinoski Park Narodowy, Izabelin, s. 43-47.

7. Misiak J. (2009), Pół wieku Kampinoskiego Parku Narodowego. Materiały z konferencji popularno-naukowej nt. „50 lat Kampinoskiego Parku Narodowego - funkcje oraz znaczenie w środowisku przyrodniczym i społecznym”. Kampinoski Park Narodowy, Izabelin, s. 19-24.

8. Okołów G. (2003), Edukacja w Kampinoskim Parku Narodowym, W: R. Andrzejewski (red.), Kampinoski Park Narodowy. t. 2, Kampinoski Park Narodowy, Izabelin, s. 161-171.

9. Osiński A. (2002), Turystyka w Kampinoskim Parku Narodowym, W: J. Partyka (red.), Użytkowanie turystyczne parków narodowych. Ojcowski Park Narodowy, Ojców, s. 239-246.

10. Partyka J. (2010), Udostępnianie turystyczne parków narodowych w Polsce a krajobraz. Prace Komisji Krajobrazu Kulturowego, nr 14, s. 252-263.

11. Rozporządzenie Ministra Środowiska z dnia 21.07.2004 r. w sprawie obszarów specjalnej ochrony ptaków Natura 2000 (Dz. U. 2004, nr 229, poz. 2313). 